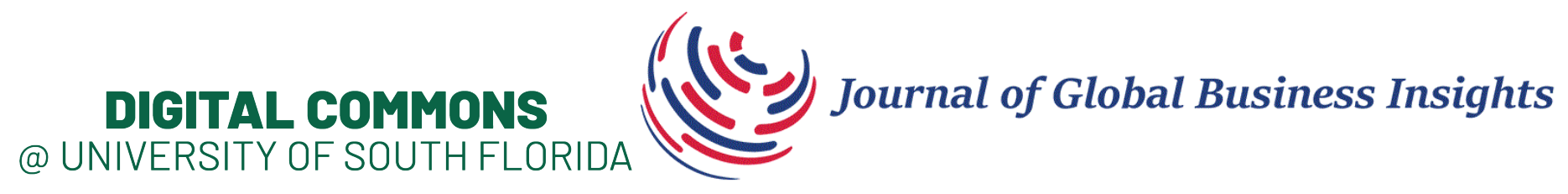

Volume 3 | Issue 2

Article 2

September 2018

\title{
Smart management systems (Triple Helix model) in Waterloo, Canada
}

Marica Mazurek

University of Zilina, marica.mazurekova@fhv.uniza.sk

Follow this and additional works at: https://digitalcommons.usf.edu/globe

Part of the Business Commons

This Refereed Article is brought to you for free and open access by the M3 Center at the University of South Florida Sarasota-Manatee at Digital Commons @ University of South Florida. It has been accepted for inclusion in Journal of Global Business Insights by an authorized editor of Digital Commons @ University of South Florida. For more information, please contact digitalcommons@usf.edu.

\section{Recommended Citation}

Mazurek, M. (2018). Smart management systems (Triple Helix model) in Waterloo, Canada. Journal of Global Business Insights, 3(2), 12-26. https://www.doi.org/10.5038/2640-6489.3.2.1033

Revisions

Submission date: Oct. 19, 2017; 1st Revision: Jan. 24, 2018; 2nd Revision: Feb. 14, 2018; 3rd Revision: Apr. 3, 2018; 4th Revision: Apr. 22, 2018; Acceptance: Aug. 3, 2018 


\title{
Smart Management Systems (Triple Helix Model) in Waterloo, Canada
}

\author{
Marica Mazurek \\ University of Zilina, Slovakia \\ marica.mazurekova@fhv.uniza.sk
}

\begin{abstract}
Knowledge, education, reputation, image, partnerships and co-creation are trends of success. The implication of the idea of interconnection of the academic environment with the business environment and public sector, which has been used in the City of Waterloo and the University of Waterloo, is an example of growing value of a territory and the development of innovative (smart) managerial decisions into a practice. The purpose of the paper is to discuss the results of research conducted in Waterloo, Ontario, Canada, which was focused on the growth of competitiveness through the implementation of smart management systems (Triple Helix Model) in the city's marketing and governance. The method of case study and qualitative research was applied by the implementation of primary and secondary research approaches. Research was conducted over a period of 4 years during post-graduate studies at the University of Waterloo, Canada. Multiple structured and unstructured interviews were conducted with representatives of the university and public and private sectors in the city of Waterloo. During the years 2011 2016, additional materials were collected in order to gain a more realistic picture. The City of Waterloo is a leader in innovations in Canada, with a large number of patents, entrepreneurship incubators, and start-ups. The University of Waterloo, situated in the city of Waterloo, has 15 patents per 10,000 residents, which is a rate four times greater than the Canadian average. Primary research results revealed that the municipality of Waterloo is strongly involved in cooperation with universities in the creation of start-up businesses.
\end{abstract}

Keywords: smart systems of management in cities, Triple Helix, partnerships with universities, high-tech industries, start-ups, governance

\section{Introduction}

Developing the competitiveness of a city forces that city and its public-sector representatives invent new methods of management and use innovative thinking. Success of cities, according to Etzkowitz (2011); Etzkowitz and Leydesdorff (2000); Etzkowitz and Zhou (2007); Ivanova and Leydesdorff (2015); Leydesdorff and Ivanova (2016); Li, Zhan, and Lu (2016); Safiullin, Fatkhiev, and Grigorian (2014); and Syed and Omar (2016), concept, has to take into account new strategies of co-operation between academic institutions and local authorities, entrepreneurs and new graduates, focused on high-tech industries and start-up businesses. This trend is based on the principles of New Economic Geography (Krugman, 1994; Porter, 1998) and the new Theory of Growth (Lewis, 2003; Romer, 1990), which emphasize the importance of knowledge capital and smart technologies. 
The educational institution in a city might be a good example of innovative and smart decisions leading to the growth of competitiveness of the city. Hjalager (2002) supported the idea of the importance of institutional innovations and Ward (1998) mentioned that universities and research institutes are key entities to promote smart technologies and decisions in a city (Triple Helix Concept). In this concept, the utilization of smart technologies and new visions is crucial. The interactive model of co-operation, embedded in the concept of an entrepreneurship university, has been used instead of the former linear model.

A territory represents a place which is significant for the economic and social development. This idea has been confirmed by Buhalis (2000), Gnoth (1998), Lusch and Webster (2011), Vargo and Lusch $(2004,2008)$. Merging of the economic and social function of territories is crucial in the perception of innovative approaches to destination marketing and, especially, city marketing from the perspectives of modern governance theories.

Porter (1985) especially considered strategy, structure and rivalry in the system of management and marketing of a territory to be the main factors of competitiveness. According to Cooper (2005) and Kotler (1984), marketing is one of the important sources of added value for a territory. Shipley and Newkirk (1998) underlined the importance of strategic and dynamic management, Mintzberg (1989) stressed the importance of innovative management.

The application of modern approaches to the strategic innovation, management and marketing of a specific territory (in our case, a city) and, especially, the implementation of modern and innovative approaches to governance (co-creation and partnerships, especially among the educational institutions of cities, public and private sector entities) has been one of the major factors of success of specific countries and, especially, cities which were able to apply innovative management and marketing tools. These good examples could be used in other cities in order to benchmark their experiences of practices for their success. One good example could be the Triple Helix model or concept, which has already been known for some time, but the application of this model could be found to be very successful in the city of Waterloo, Canada and could be good evidence of the importance of synergy between education and innovation in smart cities.

\section{Literature Review}

The creation of competitive territories requires the implementation of the factors of competitiveness and economic growth and development. For instance, Reinisto (2003) mentioned such factors as economic stability, costs, productivity, local support of services and networks, but so called soft factors are also important and are becoming crucial for cities and their competitiveness. Such factors include quality of life, culture, management, flexibility and dynamics, partnerships, and co-creation of value with customers.

Merging the factors of competitiveness with the social factors of the environment is a good example of a holistic approach to city development. The so called soft factors are based on the creation of a positive image, ethical principles, credibility and tolerance, especially the reputation of a territory. The implementation of the transparency principle is crucial in the governance of a specific city or a territory: governance, public participation, creativity, integration and cooperation in cities are becoming key conditions of the successful functioning of a city, its marketing and branding. In particular, partnerships in cities are one of the most important trends 
in marketing of territories. Kotler, Hamlin, Rein, and Haider (2002) stated that local partnerships with companies and representatives of the public sector are critical factors of success.

Similarly, the authors Go and Govers (2009) defined marketing of territories as a process of traditional segmentation, creation of product strategies, aim definition and positioning, and promotion. However, the authors underlined the necessity of co-operation among the institutions in specific territories (cities or different entities), e.g., ministries, chambers of commerce, financial institutions, etc.), but also educational and cultural institutions, entrepreneurs, and citizens.

One good example of a successful approach to the marketing of cities is place branding, which has also been supported by Go and Govers (2009), Hankinson (2001), and Reinisto and Moilanen (2009). Place branding is used for more than 20 years (Cai, 2002; Gnoth, 1998; Hankinson, 2001; Heath \& Wall, 1992; Kotler et al., 2002; Marzano, 2006; Prideaux \& Cooper, 2002; Reinisto \& Moilanen, 2009). This concept is embedded in the principle of brand equity forming, which is based on the creation of a positive image and loyalty of consumers (users of a territory). The brand equity principle is based on the creation of value with a customer and, as Go and Govers (2009), stated that place branding is mobilizing the creation of partnerships and networks between the private and public sector in order to create the offer in territories. For this reason, partnerships are crucial for the improvement of competitiveness.

It is not only partnerships of the public, private and not-for profit sector entities which are important in a territory, such as a city, but especially the mutual partnership network among the educational institutions in a city, the entrepreneurs, public sector representatives and not-for profit entities. Ward (1998) mentioned that universities and research institutes are key elements and are often important partners in public and private partnerships. The creation of a cooperative platform between a city and the academic environment (Triple Helix approach) is crucial for the establishment of potential for innovation and economic growth; moreover, it is necessary for the growth of the knowledge economy in cities and the city's successful development.

Etzkowitz and Leydesdorff (2000) studied this topic from the point of view of successful territories or cities: their research was focused on the creation of strategic alliances of academic institutions with the local public sector and entrepreneurs. They claimed that this type of partnership can create a new innovation milieu, which leads to the regeneration of the whole system in a territory. Exactly the same opinion and trends are offered by the New Theory of Growth (Lewis, 2003; Romer, 1990) and these ideas were also mentioned in the concepts of the New Economic Geography (Krugman, 1994; Porter, 1998).

These theories underline the importance of knowledge, knowledge capital and technologies and stress the necessity of governmental support in order to improve the behavioral and technological parameters of territories (cities), their processes and focus on the growth of the educational level of territories (cities), information flow, and creation of networks (partnerships). The idea of forming clusters and partnerships is crucial, especially among the educational community and the public and private entities in a city, as well as the importance of knowledge capital, technologies and the improvement of behavioral and technological parameters of cities. The proponents of these ideas were, for instance, Barro and Sala-i-Martin (1995) and Romer (1986). 
Hjalager (2002) mentioned that this might be an example of the institutional innovation. The following example (Morschett, Schramm-Klein, \& Zentes, 2009) is the system of innovation (knowledge infrastructure).

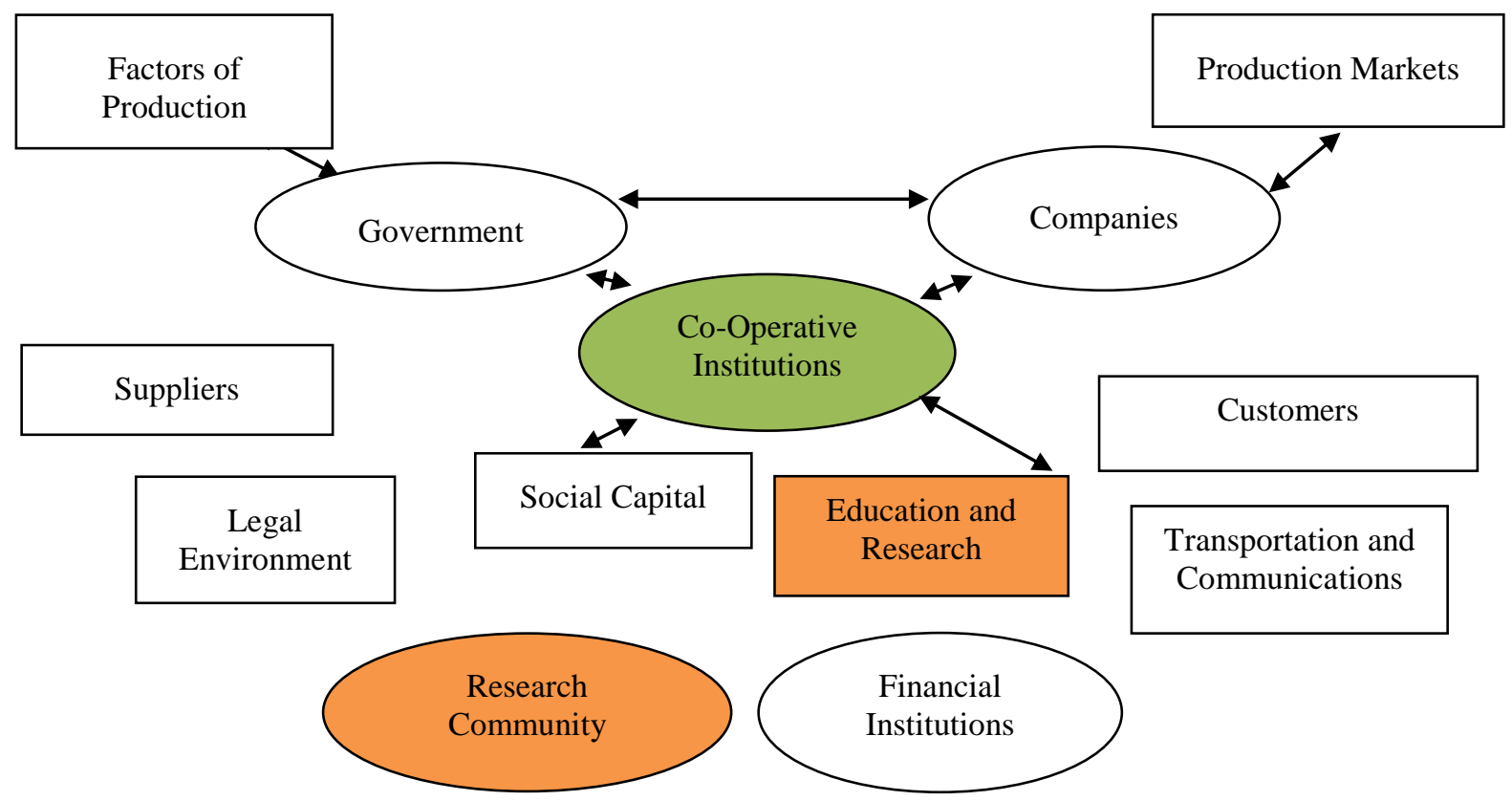

Source: Morschett et al. (2009)

Figure 1: Educational infrastructure

The main concept is the entrepreneurship-focused university, which utilizes the interactive model of innovation, instead of the linear model. The interactive model contains feedback components and the following scheme explains the concept and role of marketing and educational products, as well as the ideas of innovation incorporated in the model.

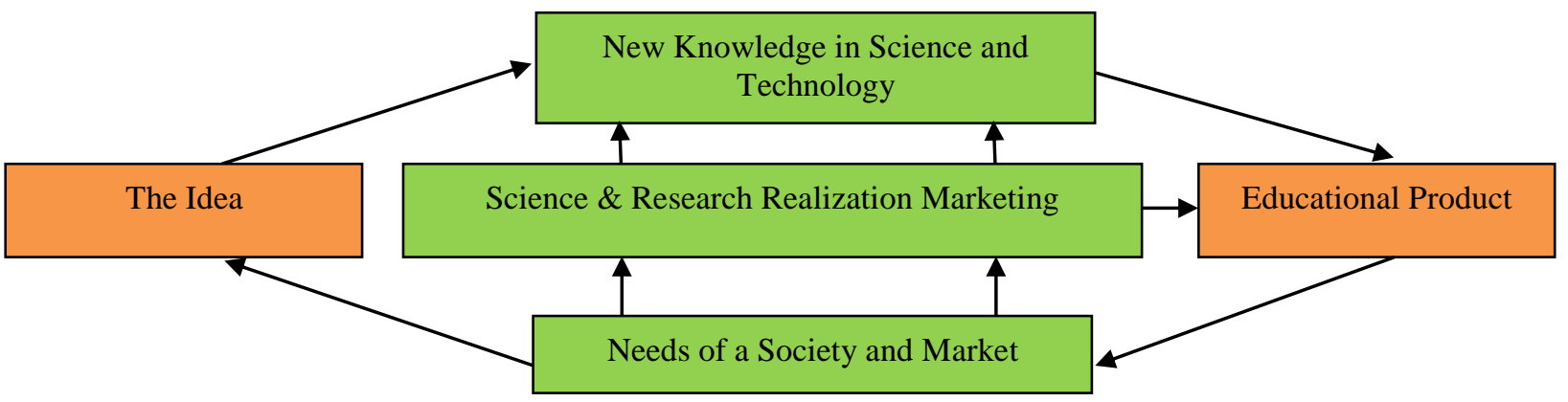

Source: Adapted from Rothwell and Zegveld (1985)

Figure 2: The interactive model of innovation (amended upon the relationship to the educational product)

This concept is embedded into the idea of continual change in the approach to the marketing of territories or cities and the creation of value with a customer (co-creation principle), which is based on the continual change of the classical paradigm of the planning process (so called Chicago School) to Neoliberalism. These ideas were stressed also by Anholt (2007). Lusch and 
Webster (2011) expressed their opinion about the necessity of the added value of marketing in territories or cities and their ideas are discussed in the following table.

Table 1: Change of Added Value of Marketing

\begin{tabular}{llll}
\hline Value creation & $\begin{array}{l}\text { Marketing } \\
\text { Value for the user }\end{array}$ & $\begin{array}{l}\text { Marketing focused on } \\
\text { the consumer }\end{array}$ & $\begin{array}{l}\text { Co-creation of value } \\
\text { with the consumer }\end{array}$ \\
\hline & $\begin{array}{l}\text { Exchange value } \\
\text { Technical equipment }\end{array}$ & $\begin{array}{l}\text { Value of use } \\
\text { Organization }\end{array}$ & $\begin{array}{l}\text { Value in the context } \\
\text { Networks }\end{array}$ \\
$\begin{array}{l}\text { Source of value } \\
\text { Conceptual base }\end{array}$ & Company and its & $\begin{array}{l}\text { Customer and market } \\
\text { Equity of co-owners }\end{array}$ & $\begin{array}{l}\text { Partners } \\
\text { Total value for partners }\end{array}$ \\
Main goal & Profit maximizing & Investments return & Flow of finances \\
Primary goal & Value creation & Fulfillment customers & Customer service \\
Financial meaning & Natural & needs & Knowledge \\
Purpose of marketing & Specialization, & Information about & Learning and education \\
Sources & centralization, & customers & Reactions to the demands \\
Main managerial concepts & competences spreading & Analyzing, planning, & of customers \\
Institutions & Private companies, & implementation, control & Perception \\
& markets, corporations, & Management, Marketing & Human rights \\
& unions of employees & Planning & Ecological norms \\
\hline
\end{tabular}

Source: Lusch and Webster (2011)

Kavaratzis and Ashworth (2008) underlined the idea that the whole process of marketing requires a tight co-operation with the users of a territory or city and this process might allow cocreation - common production of services or goods - and it leads to the strengthening of the role of a customer and a strategic priority (Heding, Knudtzen, \& Bjerre, 2009). The roles of the community, moral rules, qualitative values and ethics are becoming stronger, which has been also confirmed by Ashworth and Vooght (1990), Hankinson (2001; 2004; 2005), Kotler and Gertner (2002); and Kotler et al. (2002). For instance, Asplund (1993), Crouch and Ritchie (2003) stressed Kotler's idea of the importance of soft factors of development, e.g., niche factors of development, which mean more sustainable territorial development, quality of life improvement and cultural development. Sundbo (2008) stressed the importance of psychographic factors of demand creation. Vargo and Lusch (2004) mentioned so-called new dominant logic, which is based on the importance of services, exchange processes and relationships. It means a change of marketing theories and practice and a move from marketing management toward marketing.

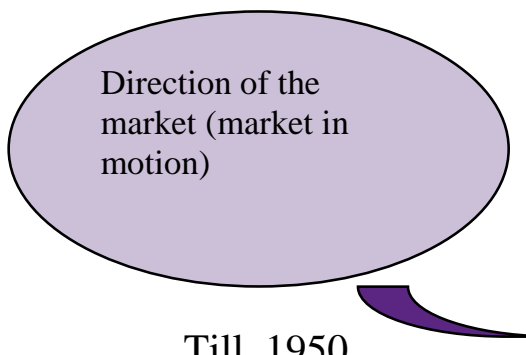

Till 1950

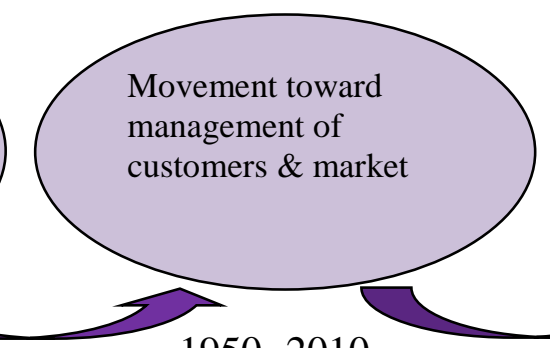

1950- 2010

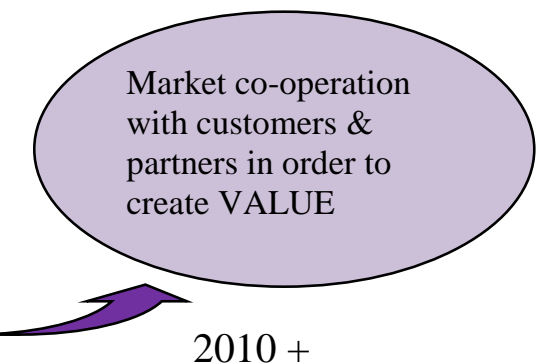

$2010+$

Source: Lusch et. al. (2007)

Figure 3: Development of marketing, partnership and co-creation

A change also appears in the perception of partnerships among the creators and users of strategies and it opens a space for co-creation and co-production, as has been mentioned by Lusch, Vargo, and O'Brien (2007), where the idea of co-operation is merged into one process 
and changes the view of marketing and partnerships. The idea of partnerships is one of the basic concepts of success and competitiveness (for instance, Poon's model of competitiveness). The role of partnerships and co-creation of value with a customer is crucial for the creation of successful strategies of territorial development. For this reason, cities should focus their attention on the question of co-creation of value with customers and users of a territory.

Vargo and Lusch (2006) stated that the customer is always a value creator and this fact is a main factor of success for the creation of a competitive and innovative marketing strategy concept for territorial or city development. These ideas have also been stressed by authors such as Prahalad and Ramaswarny $(2000 ; 2004)$.

These three trends - strengthening the role of governance, the importance of partnerships and the creation of value with the users of a territory or city, e.g., co-creation, could be considered as crucial factors of competitiveness improvement. In accordance with the neoliberal approach to the management of territories or cities, several authors, such as Boisen (2007a), Boisen (2007b), Boisen (2012) tried to combine the traditional approach to marketing with the concept of governance, creation of partnerships (collaborative governance) and co-creation processes (participatory governance).

Another important trend in the marketing of cities is the process of strengthening creativity and creating creative clusters, as well as the creation of smart cities.

In accordance with the newest trends of development and competitiveness should be mentioned some new concepts and ideas, which have been developed, for instance, at the 3rd Global Summit on city tourism New paradigms in City Tourism Development in Barcelona, where Buhalis (2014) defined a smart territory as a territory which is characterized by its innovative approach and development, and invests in its human and social capital. Participatory governance, partnerships, technologies, human and social capital are all crucial aspects of a smart territory or city, as has been noted in the following scheme by Buhalis (2014). This concept does not only concern tourism development, but could be generalized to the other activities in a city.

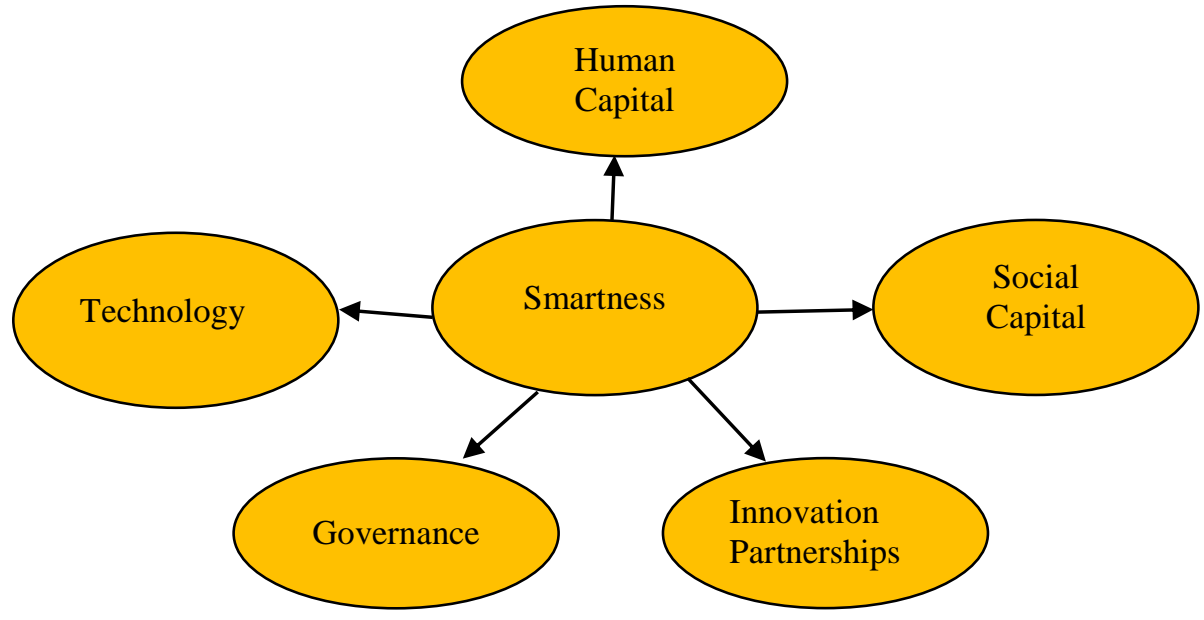

Source: Buhalis (2014)

Figure 4: Smart city 
Several successful cities in Europe served as an example for the creation of the model of a smart city (Figure 4) based on the combination of the following characteristics: smart economy, smart mobility, smart environment, smart people, smart living conditions, smart governance. Such authors as Anthopouls and Vakali (2011), Carvalho (2015), Hollands (2015), Kitchin (2015), Nam and Pardo (2011), Shelton, Zook, \& Wiig (2015), Suzuki and Finkelstein (2013), Suzuki (2017) supported the idea of smart city creation and development.

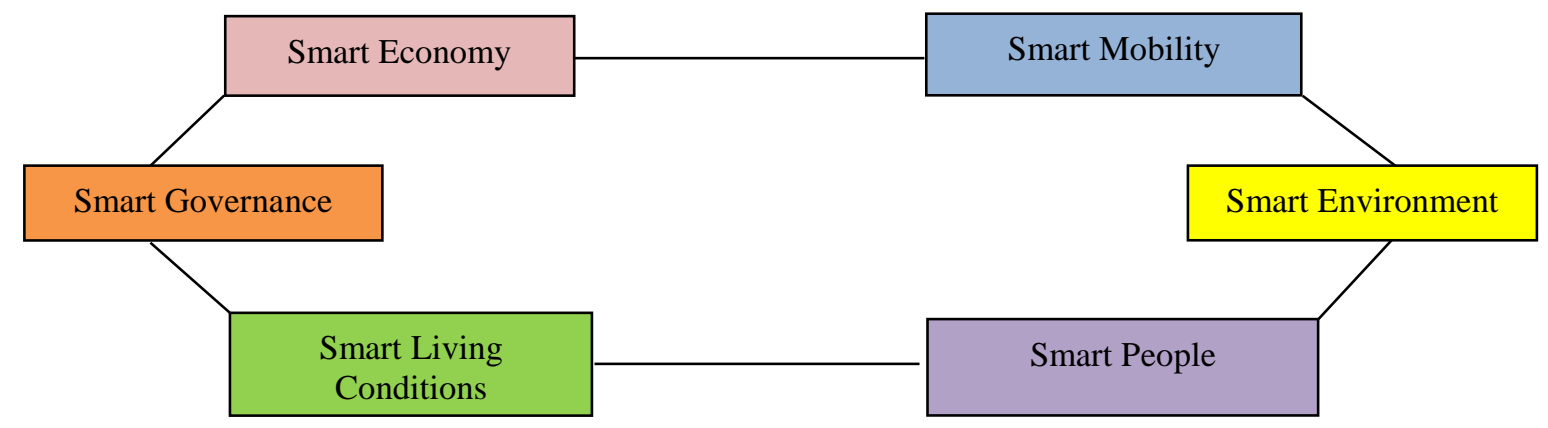

Source: www.smart-cities.eu, 2016

Figure 5: Model of a smart city

Merging the modern technological environment with the ethical social environment and the economic environment is a precondition of the innovative development of cities. The following 6-stars model contains the requirements for the successful development of a city.

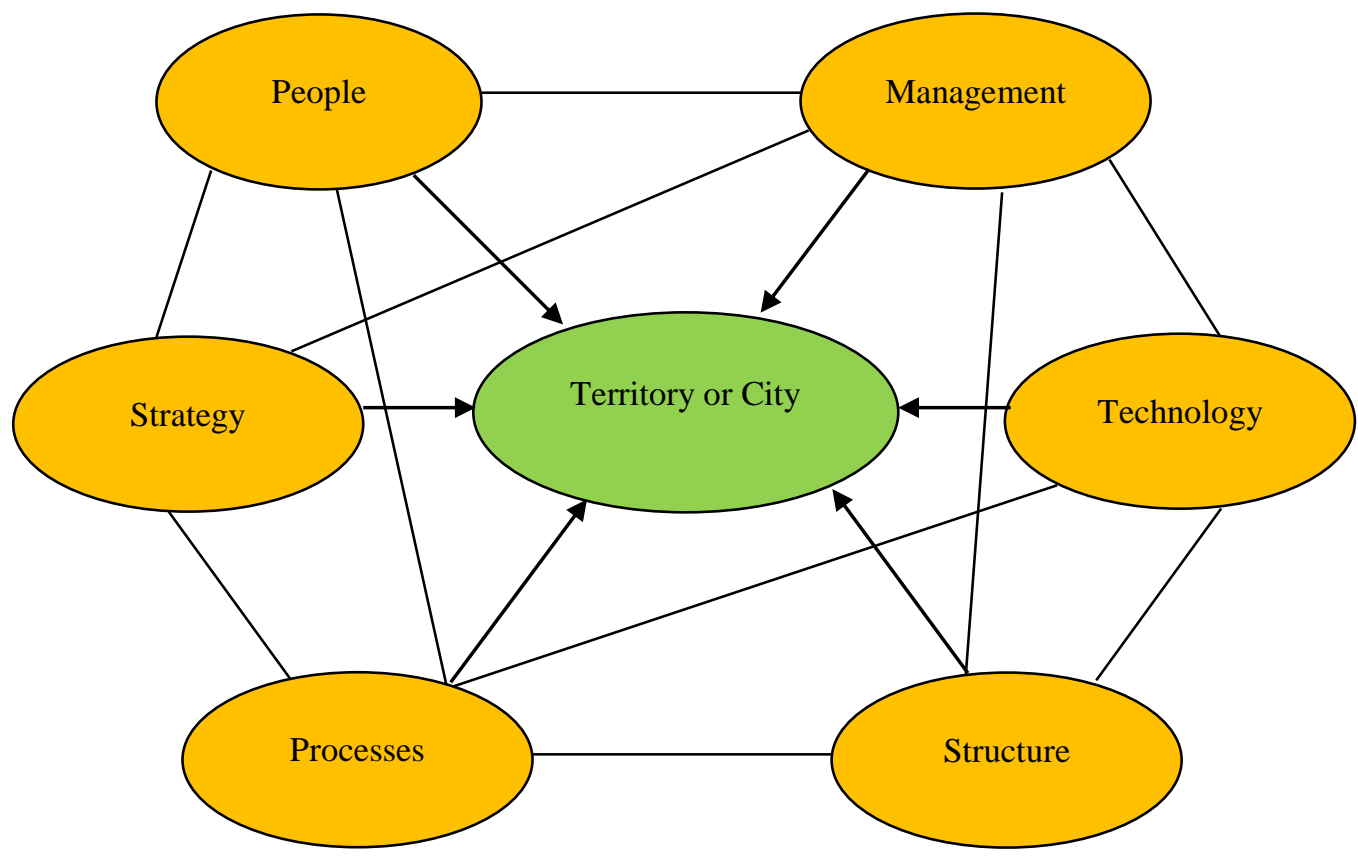

Source: Adapted from Lendel, 2009

Figure 6: Six Stars model amended for the territorial purposes (concept of CCM)

Applications of these approaches and models are visible in many successful cities in the world. The application of the Triple Helix approach and smart city concepts are especially present in cities, which are competitive, popular among entrepreneurs, students and citizens. The success 
stories of these cities, territories and countries might be a good example for other cities which are looking for a better position and managerial progress. One such territory is Canada's Technological Triangle; Kitchener-Waterloo-Guelph. In our study, we were mostly focused on the city of Waterloo, which is home to the most innovative university of Canada, the University of Waterloo.

\section{Methodology}

During this study, both primary and secondary research approaches were applied. The sources of secondary research were internet publications, projects dealing with the studied topic, especially dealing with partnerships and smart destinations, and materials about the municipality of Waterloo. Primary sources of the research were principally discussions with representatives of the public sector in the city of Waterloo and academics from the University of Waterloo during a postgraduate study stay at the University of Waterloo from 2006-2010.

In this period of research, representatives of the academic environment, e.g. professors, administrators of the University of Waterloo were interviewed both formally and informally. Some of the interviewed academics were members of public-private partnerships and had expertise as the governmental representatives in specific commissions and boards. The case study method was followed, using qualitative research to obtain results which created a picture of the case of Waterloo and indicate the reasons for its success story. This research was conducted in several stages during the stated period of time, especially during the personal stay in Canada; however, some later period should also be mentioned, especially the years 2011 till 2016, when additional materials were collected during additional visits and research in Canada and through personal and digital contact and correspondence (e-mails, Skype, Facebook, etc.).

Concerning the case-study research method, Creswell (2009), Stake (2005), Yin (2009; 2004; 2003) and others recommend this method as suitable for the application of the inductive approach, which allows applying existing theories. Creswell (2007) stressed the importance of this method, especially if a researcher wanted to apply several sources of results during a longer period of time in order to achieve richness of data and understanding of a problem. The casestudy method has been supported by Creswell (2002), Patton (2002), Xiao and Smith (2006), The method of structured and unstructured discussion was used for the improvement of the empirical research, which is also our own research and the findings are based on the primary and, mostly, secondary sources. Empirical research is a first stage of research, which might create a thorough picture of the case under examination and is especially based on personal experience, which has been incorporated into the findings. The originality of the research and findings is that they are not only based on existing sources, but a researcher had to personally experience the innovative environment during an extended period. Discussions were conducted face-to-face or online, by e-mails or personally, and some questions were repeated to obtain a clearer picture. Several other methods have been used, for instance, analysis of results, comparative analysis, synthesis, analogy, generalization, etc.

\section{Findings}

The Waterloo region, with over half a million citizens, is familiar for its competitiveness in Canada, and the city of Waterloo with its approximately 113 thousand inhabitants bears the same 
designation as the whole region. The City of Waterloo is known as a part of the so-called Technological and Knowledge Triangle, whose fame is based on high-tech technologies in cooperation with one of the most innovative universities, not only in Ontario and Canada, but all over the world. Waterloo University is one of the best universities in the world and, in the ranking of MacLean's, occupies the first place for innovations in the Canadian university environment (MacLean's, 2015).

The university is predominantly science-oriented and the newest study programs are focused on nanotechnologies. The study programs are closely connected with practical applications and entrepreneurship platforms, such as the Science and Technological Park Research in Motion (RIM), which was familiar for the production of BlackBerry cell phones. Waterloo is also home to Wilfred Laurier University, with a strong Business program. The University of Waterloo has a campus also in Abu Dhabi in the United Arab Emirates, but, based on the latest research, the University of Waterloo cannot recruit the expected number of students in Dubai after three years of existence. A partnership with the United Arab Emirates Higher Colleges of Technology still does not guarantee the full number of planned students (about 500), and for this reason the University of Waterloo had to shutter its branch campus in Dubai. It might be important not only to co-operate and create a partnership, but also to take into account the location and the opportunities for continuous growth.

The former Rector of Wilfred Laurier University, Robert G. Rosehart, mentioned that Waterloo region contains all parts which are important for a success: The educated and skilled labor, best academic capacity and local educational institutions and the ability to attract investors in order to gain a financial success (The Record, 2013). Besides the international high-tech company, RIM, Waterloo City is a seat of many important companies; for example, D2L (formerly Desire2Learn), McAfee, Agfa, Sybase, Google, Electronic Arts, Dalsa and Sandvine, Kik Interactive, Miovision Technologies, Thalmic Labs, etc. Waterloo is also a seat of the Perimeter Institute for Theoretical Physics, which is focused on research in technologies (nanotechnologies) and physics. Other partners of the educational institutions and the city are The Centre for International Governance Innovation and the Institute for Quantum Computing.

The City of Waterloo is a leader in innovation in Canada with the highest index of patents, entrepreneurship incubators and start-ups. Results of primary research revealed that ethics, a positive image and good governance are important for the success of Waterloo. The respondents mentioned especially the importance of investment and entrepreneurship opportunities, culture, quality of educational facilities, health care, social services, employment opportunities, etc. Waterloo ranks as the $25^{\text {th }}$ city in the world in the creation of ecosystems and start-ups. For this position, the city had to be one of the leaders in partnerships, technical talents and, especially, to be a place of an existing academic environment with two excellent universities.

The municipality of Waterloo is strongly involved in co-operation with the universities, especially the University of Waterloo, in the creation of start-up businesses. There are Business Educational Partnerships which allow the students to take part in practical education in local businesses. Governmental support is crucial, together with mutual financial help from public sources and additional support from private sources for scientific and technological purposes. One example is the network Communitech and Accelerator Centre as a subject of mutual cooperation between the universities and the professional entrepreneurship entities. The University 
of Waterloo creates partnerships with the region of Waterloo, city of Waterloo, and cities of Kitchener, Cambridge, Stratford, Dumfries, Wellesley, Wilmont and Woolwich.

The University of Waterloo is tightly joined in a co-operation with the Chamber of Commerce and the Deputy for Entrepreneurship (CAO). An important partner for the University of Waterloo is Communitech, which is also a sponsor of several events in the city, for instance Waterloo Innovation Summit, Techtoberfest, TechLeadership Conference and a Startup Weekend. One important example of co-operation between the University of Waterloo and its partners is the pilot program ASCEnt (Accelerating Social Cause Entrepreneurs). Close cooperation of the academic institutions and city of Waterloo with the twin city of Kitchener have doubled the investments into both cities, especially in the area of the use of 3D technologies in health care, the entertainment business, architecture, internet media, digital publications and music. The Government of Ontario also supports financially the creation of start-ups in the province in a program called Entrepreneurs Residence and the MaRS Market Intelligence program. For example, in 2014, the investment of Canada into start-ups was more than 2.3 billion CAD.

The University of Waterloo co-operates tightly with the American Silicon Valley, with exchanges of students, practices, and experts. The City of Waterloo established special centers in the city, which contains about 6000 companies with approximately 250 thousand employees in the IT sector of Ontario. One example is Ontario Technology Corridor. The IT technologies sector in this city represents an entity which is able to create $20 \%$ of the GDP of Canada. The Accelerator Centre Directly is placed at the University of Waterloo and supports the entrepreneurship of high-tech technological companies.

One of the latest examples of the partnership of the city of Waterloo, in order to become a leading smart city in the world and create an intelligent community, is the creation of a strategic partnership with the company Intuitive Business Intelligence Today and the company OpenText. In 2007, the City of Waterloo was designated in New York as a member of the world's intelligent communities (ICF). An important factor for the city is a close co-operation with both universities and the improvement of governance in the city. For instance, it resulted in the creation of so-called information governance (Enterprise Information Management), which is focused on cloud-based management and techniques, integration of data, regulation, etc. Tight co-operation exists among the partners of the city and the university with several think-tanks, including, for instance, the Perimeter Institute, Center for International Governance, institutions of creative business. As an example of mutual successful co-operation between the University of Waterloo and other partners in the city could be mentioned two case studies - the Communitech partnership and Velocity.

Case Study Communitech is a partnership of 450 partners, mostly focused on innovations, leadership, networks, and promotion. Communitech is a partnership which aims to support technological companies in the whole region, in the cities of Waterloo and Kitchener and the creation and support of the whole territory as the technological cluster and the creation of the digital network Canadian Digital Media Network (CDMN) (Communitech, n.d.).

Another good example of partnership is MIN (Manufacturing Innovation Network) as a partnership of local producers, academic institutions, municipal government, and associations 
involved in marketing, network creation and innovations. The goal of MIN is to centralize emarkets and innovation activities as well as the creation of brand awareness.

Case Study Velocity is an example of the co-operation of the University of Waterloo with the local entrepreneurship environment. A similar program at the Wilfred Laurier University is called Launchpad. Since 2008 Velocity enabled to establish 160 start-up companies, collected about 250 million CAD, and created about 800 working positions. The company, Velocity, usually does not reveal its annual budget, but it is well known that it collected for its activities in the past approximately 2 million CAD as a personal gift from the company Kik and its founder Teda Livingston, as well as having financial support from the Ontario government and Canadian government.

Since 2008 Velocity has been interconnected with six entrepreneurship activities: Velocity Residence, Velocity Garage, Velocity Alpha, Velocity Science, Velocity Foundry and Velocity Fund Finals (VFF). It is crucial that this start-up nursery is focused on education and has been placed at the University of Waterloo. In the framework of this co-operation, 75 companies have been established in the City of Waterloo and 45 other new companies (all together 120 companies) are ready to start.

One of the latest examples of mutual co-operation and interest was a visit of the Prime Minister of Canada Justin Trudeau to the University of Waterloo in January 2016, where the Canadian government offered the investment of 12 million CAD for the activities of SOWC (Southern Ontario Water Consortium), which creates a partnership of 90 enterprises, not-for profit companies co-operating in about 80 projects. 6 faculties of the University of Waterloo are involved in these activities. Prime Minister Trudeau supported the activity of Velocity and startup creation and, according to information from January 2016, based on his support has granted financial support of 12 million CAD for creation of start-ups in the Velocity system. Based on this financial support from the Canadian government, the University of Waterloo could strengthen the capacity of its business. Additionally, it allowed the university to enlarge the area of the Velocity company from $2600 \mathrm{~m}^{2}$ to $7000 \mathrm{~m}^{2}$, which means more than double the area of Velocity's start-up capacity. This is an excellent example of governmental support and the openness of public sector representatives to support smart technologies.

The idea of entrepreneurship is focused on the young entrepreneurs who are interested in creating new start-ups at the University of Waterloo and in the City of Waterloo. An interesting contribution is also the Velocity Residence program, which offers accommodation facilities for the young entrepreneurs in the city and at the university and the availability of the Velocity Fund, which is able to offer annually financial grants of 375 thousand CAD for young entrepreneurs. One example of the success of the Velocity company is so called LibertyBit, on which is based the Bitcoin financial exchange system as an innovative form of world finance.

\section{Conclusion}

The functioning of partnerships, excellent reputation and the image of a place are important for a city, especially partnerships with academic institutions and research institutes. 


\section{Theoretical Implications}

Knowledge capital and smart technologies in cities, as well as partnerships among educational institutions and private and public-sector representatives are based on several opinions of different authors, such as Etzkowitz and Leydesdorff (2000), and are important tools of success in the period of growth of smart technologies. Innovations which are institutionally based (Hjalager, 2002) stress the value of research institutes, smart technologies and smart decisions in cities, which is confirmation of the idea that the Triple Helix concept is really important for cities which want to succeed.

The application of modern approaches to strategic innovation management and marketing of a specific territory (in our case a city) and the implementation of modern and innovative approaches to governance (co-creation and partnerships, especially among the educational institutions of cities, public and private sector entities) has been one of the major factors of success of specific countries, and especially cities, which were able to apply innovative management and marketing tools. It has been studied in several conceptual materials before starting of this research.

\section{Practical Implications}

Education, knowledge, reputation, image, partnerships and co-creation are nowadays trends of success. For this reason, it is not a surprise that several private entrepreneurial businesses supported research and education at the University of Waterloo and contributed almost $10 \%$ of their profits for educational and research purposes. Investment and partnerships with universities, which are not only innovative, but also offer the educational product at a high-quality level, is one of the preconditions of effective leadership and success. Waterloo is one good example of it and many cities and universities should learn from it. It should be a rule in countries where education is not a priority.

Waterloo University and the City of Waterloo are excellent examples of this mutual co-operation and the success story of the Kitchener-Waterloo Region, Province of Ontario and the whole of Canada. The idea of interconnection of the academic environment with the business milieu and public sector in a city gives an advantage, which is crucial for success. The value for territories is especially in partnership co-operation and mutual trust, good image and reputation, giving them a competitive advantage, and not only in terms of recognized advantage components such as, for instance, natural resources, history or culture. Management, marketing, human capital, safety and partnerships might be decisive when similar territories exist, but do not apply the same tools of management and marketing or are more or less vulnerable. Nowadays, competitive advantage is a tool of success in territories and cities. For this reason, many cities, even with a sound comparative advantage potential, but without great managerial or leadership skills or marketing strategies, and without the investment in knowledge potential and reputation, could rank lower in competitiveness.

\section{Limitations and Future Research}

One limitations of this research could be that this is only a part of the research conducted and planned in Canada, which was done during the period 2006-2010 in the framework of post- 
graduate studies at the University of Waterloo. The second phase of this research was added later, in the years 2011-2016. The limitation could be the different time frame for this type of research and probably the influence of technical and managerial changes during the period of 10 years since it started.

Future research regarding smart management systems and the application of the Triple Helix Model might be more focused on the comparison of some different countries and their most innovative universities. This comparison could be helpful for governments and the universities to understand several cultural disparities when dealing with innovations and managerial decisions. Despite the high level of competitiveness and innovations, some cities and countries might suffer from cultural influence and differences. For this reason, it might be interesting to compare how, for instance, the Triple Helix Model might exist in some Asian or Muslim countries and compare them in order to achieve a multidimensional theoretical and practical knowledge of smart management in the world.

\section{References}

Anholt, S. (2007). Competitive identity: The new brand management for nations, cities and regions. Journal of Brand Management, 14, 474-475.

Anthopouls, L. G. \& Vakali, A. (2011). Urban planning and smart cities: Interrelations and reciprocities. Berlin, Germany: Springer.

Ashworth, G., J. \& Vooght, H. (1990). Selling the city: Marketing approaches in public sector urban planning. London, UK: Belhaven.

Asplund, C. (1993). Placehunting international: Om konsten att gora sig mer attraktiv for investeringar. Stockholm, Sweden: EuroFutures

Barro, R. \& Sala-i-Martin, X. (1995). Economic growth: Advanced series in economics. New York, NY: McGrawHill.

Boisen, M. (1995). The role of city marketing in contemporary urban governance. Retrieved from http://bestplaceinstytut.org/www/wp-content/uploads/2012/08/Boisen-2007-City-marketing-inContemporary-Urban-Governance.pdf

Boisen, M. (2007a, September). City marketing in contemporary urban governance. Paper presented at the $51^{\text {st }}$ World Conference of the International Federation of Housing and Planning (IFHP), Copenhagen, Denmark.

Boisen, M. (2007b). Strategic marketing for middle-sized cities in the Netherlands (Unpublished master thesis). University of Utrecht, Netherlands.

Buhalis, D. (2000). Marketing the competitive destination of the future. Tourism Management, 21(1), $97-116$.

Buhalis, D. (2014). Contribution on smart tourism to the UNWTO 3rd Global Summit on city tourism: New paradigms in city tourism development. Retrieved from http://blogs.bournemouth.ac.uk/ekotourismlab/research-projects/phd-projects/smart-tourism-destinationsexplore-how-smartness-increases-competitiveness-in-the -context-of-tourism-destinations

Cai, L. (2002). Cooperative branding for rural destinations. Annals of Tourism Research. 29(3), 720-742.

Carvalho, L. (2015). Smart cities from scratch? A socio-technical perspective. Cambridge Journal of Regions, Economy and Society, 8, 43-60.

Communitech. (n.d.). Canadian digital media network receives $\$ 8.75 \mathrm{M}$ in funding. Retrieved from https://www.communitech.ca/press-release/canadian-digital-media-network-receives-8-75m-in-funding/

Cooper, C. (2005). Knowledge management in tourism. Annals of Tourism Research, 33(1), 47-64.

Creswell, J. W. (2002). Educational research: Planning, conducting, and evaluating quantitative and qualitative research. Upper Saddle River, NJ: Merrill/Pearson.

Creswell, J. W. (2007). Qualitative inquiry and research design: Choosing among five traditions. Thousand Oaks, CA: Sage.

Creswell, J. W. (2009). Research design: Qualitative, quantitative, and mixed methods approaches. Thousand Oaks, CA: Sage.

Crouch, G. I., \& Ritchie, J. R. B. (2003). The competitive destination: A sustainable tourism perspective. Cambridge, UK: CABI. 
Etzkowitz, H. (2011). Triple Helix: Science, technology and the entrepreneurial spirit. Journal of Knowledge-Based Innovation in China, 3(2), 76-90.

Etzkowitz, H., \& Leyedesdorff, L. (2000). The dynamics of innovation: From national systems and 'mode 2' to a triple helix of university -industry-government relations. Research Policy, 29(2), 109-123.

Etzkowitz, H., \& Zhou, C. (2007, May). The entrepreneurial university in various Triple Helix models. Paper presented at Singapore Triple Helix VI Conference, Singapore.

Gnoth, J. (1998). Conference reports: Branding tourism places. Annals of Tourism Research, 25, 758-760.

Go, F. \& Govers, R. (2009). Place branding. London, UK: Palgrave MacMillan.

Hankinson, G. (2001). Location branding: A study of twelve English cities. Journal of Brand Management, 9(2), $127-142$.

Hankinson, G. (2004). Relational network brands: Towards a conceptual model of place brands. Journal of Vacation Marketing, 10, 109-121.

Hankinson, G. (2005). Destination brand images: A business tourism perspective. Journal of Service Marketing, $19(1), 24-32$.

Heath, E., \& Wall, G. (1992). Marketing tourism destinations: A strategic planning approach. Hoboken, NJ: John Wiley and Sons.

Heding, T., Knudtzen, C. F., \& Bjerre, M. (2015). Brand management: Research, theory and practice. Oxon, MD: Routledge.

Hjalager, A. M. (2002). Repairing innovation defectiveness in tourism. Tourism Management, 23(5), 465-474.

Hollands, R. (2015). Critical interventions into the corporate smart city. Cambridge Journal of Regions, Economy and Society, 8, 61-77.

Ivanova, I. A., \& Leydesdorff, L. (2015). Knowledge-generating efficiency in innovation systems: The acceleration of technological paradigm with increasing complexity. Technological Forecasting and Social Change, 96, 254-265.

Kavaratzis, M., \& Ashworth, G. (2008). Place marketing: How did we get here and where are we going? Journal of Place Management and Development, 1(2), 150-165.

Kitchin, R. (2015). Making sense of smart cities: Addressing present shortcomings. Cambridge Journal of Regions, Economy and Society, 8, 131-136.

Kotler, P. (1984). Marketing management: Analysis, planning and control. New Jersey, NJ: Prentice Hall.

Kotler, P., \& Gertner, R. (2002). Country as brand, product and beyond: A place marketing and brand management perspective. Journal of Brand Management, 9(4/5), 249-261

Kotler, P., Hamlin, M. A., Rein, I., \& Haider, D. H. (2002). Marketing Asian places: Attracting investment, industry and tourism to cities, states and nations. Singapore: John Wiley \& Sons (Asia).

Krugman, P. (1994). Competitiveness - A dangerous obsession. Foreign Affairs, 73(2), 28-44.

Lendel, V. (2009). The knowledge in strategic decision making (Doctoral dissertation, University in Žilina. Retrieved from http://www.fri.uniza.sk/uploads/phd/23f-Dizertacna\%20praca\%20bizik.pdf

Lewis, W. A. (2003). The theory of economic growth. Oxon, UK: Routledge.

Leydesdorff, L., \& Ivanova, I. A. (2016). "Open innovation" and "Triple Helix" models of innovation: Can synergy in innovation systems be measured? Journal of Open Innovation: Technology, Market and Complexity, 2(1), 1-12.

Li, W., Zhan, J., \& Lu, Y. (2016). A study of transformational leadership, strategic flexibility, and a firm performance: The moderating role of environmental dynamism. International Interdisciplinary BusinessEconomics Advancement Journal, 1(2), 73-84.

Lusch, R. F., \& Webster, F. E. (2011). A stakeholder-unifying, cocreation philosophy for marketing. Journal of Macromarketing 31(2), 129-134.

Lusch, R. F., Vargo, S. L., \& O’Brien, M. (2007). Competing through service: Insights from service-dominant logic. Journal of Retailing 83(1), 5-18.

MacLean's (2015). National reputational ranking Retrieved from http://www.macleans.ca/education/nationalreputational-ranking-2016

Marzano, G. (2006, January). Relevance of power in the collaborative process of destination branding. Paper presented at 11th Annual Conference on Graduate Education and Graduate Student Research in Hospitality and Tourism, Seattle, USA.

Mintzberg, H. (1989). Mintzberg on management. London, UK: The Free Press

Morschett, D., Schramm-Klein, H., \& Zentes, J. (2015). Strategic international management. London, UK: Springer. 
Nam, T., \& Pardo, T. A. (2011, September). Smart city as urban innovation: Focusing on management, policy and context. Paper presented at the 5th International Conference on Theory and Practice of Electronic Governance (ICEGOV2011), Tallinn, Estonia.

Patton, Q. (2002). Qualitative research and evaluation methods. Thousand Oaks, CA: Sage.

Porter, M. (1985). Competitive advantage. New York, NY: Free Press.

Porter, M. E. (1998). Clusters and new economies of competition. Harvard Business Review, 76, 77-90.

Prahalad, C. K., \& Ramaswamy, V. (2004). Co-creation experiences: The next practice in value creation. Journal of Interactive Marketing, 18(3), 5-14.

Prahalad, C. K., \& Ramaswarny, V. (2000). Co-opting customer competence of the corporation. Harvard Business Review, 78, 79-87.

Prideaux, B., \& Cooper, C. (2002). Marketing and destinations growth: A symbiotic relationship or simple coincidence? Journal of Vacation Marketing, 9(1), 35 - 48.

Reinisto, S. K. (2003). Success factors of place marketing: A study of place marketing practices in Northern Europe and the United States (Doctoral dissertation, Helsinki University of Technology). Retrieved from http://lib.tkk.fi/Diss/2003/isbn9512266849/

Reinisto, S., \& Moilanen, T. (2009). How to brand nations, cities and destinations. Basingstoke, UK: Palgrave Macmillan.

Romer, P. M. (1986). Increasing return and long-run growth. The Journal of Political Economy, 94(5), 1002-1037.

Romer, P. M. (1990). Human capital and growth: Theory and evidence. Carnegie-Rochester Conference Series on Public Policy, 32(1), 251-286.

Rothwell, R., \& Zelveld, W. (1985). Reindustrialization and technology. Harlow, UK: Longman.

Safiullin, L. N., Fatkhiev, A. M., \& Grigorian, K. A. (2014). The Triple Helix model of innovation. Mediterranean Journal of Social Sciences, 5(18), 203-206.

Shelton, T., Zook, M., \& Wiig, A. (2015). The 'actually existing smart city'. Cambridge Journal of Regions, Economy and Society, 8, 13-25.

Shipley, R., \& Newkirk, R. (1998). Visioning: Did anybody see where it came from? Journal of Planning Literature, 12(4), 407-416.

Stake, R. (2005). Case studies in handbook of qualitative research. Thousand Oaks, CA: Sage.

Sundbo, J. (2008). Creating experiences in the experience economy. Cheltenham, UK: Edward Elgar.

Suzuki L.R. (2017). Smart cities IoT: Enablers and technology road map. In S. Rassia, \& P. Pardalos (Eds.) Smart city networks: Springer optimization and its applications (pp. 167-190), Cham, Switzerland: Springer.

Suzuki, L. R., \& Finkelstein, A. (2013). An introduction to digital cities. Retrieved from http://www.smartcityresearch.com/2013/07/an-introduction-to-digital-cities.html

Syed, O. R., \& Omar, R. (2016). Restoring the relevance: Conceptualizing and collaborating model for business schools. International Interdisciplinary Business-Economics Advancement Journal, 1(2), 85-93.

The Record. (2013). 2013 statistics and facts. Retrieved from https://www.therecord.com/communitystory/3849405-2013-statistics-and-facts/

Vargo, S. L., \& Lusch, R. F. (2004). Evolving to a new dominant logic for marketing. Journal of marketing. 68(1), $1-17$.

Vargo, S. L., \& Lusch, R. F. (2006). The service-dominant logic of marketing: Reactions, reflections, and refinements. Marketing Theory, 6(3), 281-288.

Vargo, S. L., \& Lusch, R. F. (2008). Service-dominant logic: Continuing the evolution, Journal of the Academy of Marketing Science, 36(1), 1-10.

Ward, S. V. (1998). Selling places - The marketing and promotion of towns and cities 1850-2000. London, UK: Routledge.

Xiao, H., \& Smith, S. (2006). The making of tourism research: Insights from a social science journal. Annals of Tourism Research, 33(2), 490-507.

Yin, R. K. (2003). Case study research: Design and methods (3 ${ }^{\text {rd }}$ ed.). Newbury Park, CA: Sage.

Yin, R. K. (2004). The case study anthology. Thousand Oaks, CA: Sage.

Yin, R. K. (2009). Case study research: Design and methods (4 ${ }^{\text {th }}$ ed.). Newbury Park, CA: Sage. 